\title{
42. ORGANIC GEOCHEMISTRY OF CRETACEOUS MUDSTONES AND MARLY LIMESTONES FROM DSDP SITES 400 AND 402, LEG 48, EASTERN NORTH ATLANTIC
}

\author{
G. Deroo, J. P. Herbin, J. Roucaché, and B. Tissot, Institut Français du Petrole, Division Geologie, Rueil-Malmaison, \\ France
}

\section{INTRODUCTION}

The study intends to characterize, from a geochemical point of view, the organic matter present in the Albian-Aptian series drilled at Sites 400 and 402 in the Bay of Biscay (Figure 1).

To this end, a pyrolysis assay on raw samples was followed by a chloroform extraction of some selected samples. Elemental analysis of kerogen and carbon analysis of humic compounds were then carried out to complete the geochemical outline.

\section{SAMPLING}

In Hole 400A the Upper Cretaceous (Unit 3) sediments are marly nannofossil chalks. These chalks are associated with calcareous claystones and carbonaceous mudstones in the Albian and Aptian of Unit 4 (Figure 2). Carbonaceous material also characterizes the Albian-Aptian series in Hole $402 \mathrm{~A}$.

Twelve large samples were collected for detailed analysis. Seventy-one small samples were pyrolyzed to complete the on-board study started during Leg 48 (see Geochemistry Section, Site Chapter, this volume). These latter were selected from Cores 61 to 72 in Hole $400 \mathrm{~A}$ and from Cores 10 to 35 in Hole 402A.

\section{ANALYTICAL METHODS}

The analytical procedures, outlined in Figure 3, were described in previous papers from Legs $41,42 \mathrm{~A}, 44$ and recently from Legs 47A and 47B (Deroo, et al., 1979a, b) of Atlantic DSDP cruises.

\section{DETAILED RESULTS}

\section{Mineral Carbon (Table 1)}

At Hole 400A Cores 61 to 63 have the highest mineral carbon values ( 4.40 to 7.20 per cent of mineral carbon) compared to the underlying Cores 64 to $72(0.40$ to 4.44 per cent). On-board analysis shows an equivalent contrast between Cores 61 to 63 ( 20 to 30 per cent carbonate) and Cores 64 to 72 (in general, less than 15 per cent). However the on-board data always indicated a lower carbonate content than the data reported here.

At Hole $402 \mathrm{~A}$ the vertical distribution of mineral carbon is rather uniform ( 2.52 to 5.80 per cent) except for the bottom Cores 34 and 35 where it reaches 7.04 and 8.32 per cent, respectively. Here again the same contrast appeared between shore and on-board data, the latter indicating lower carbonate contents.

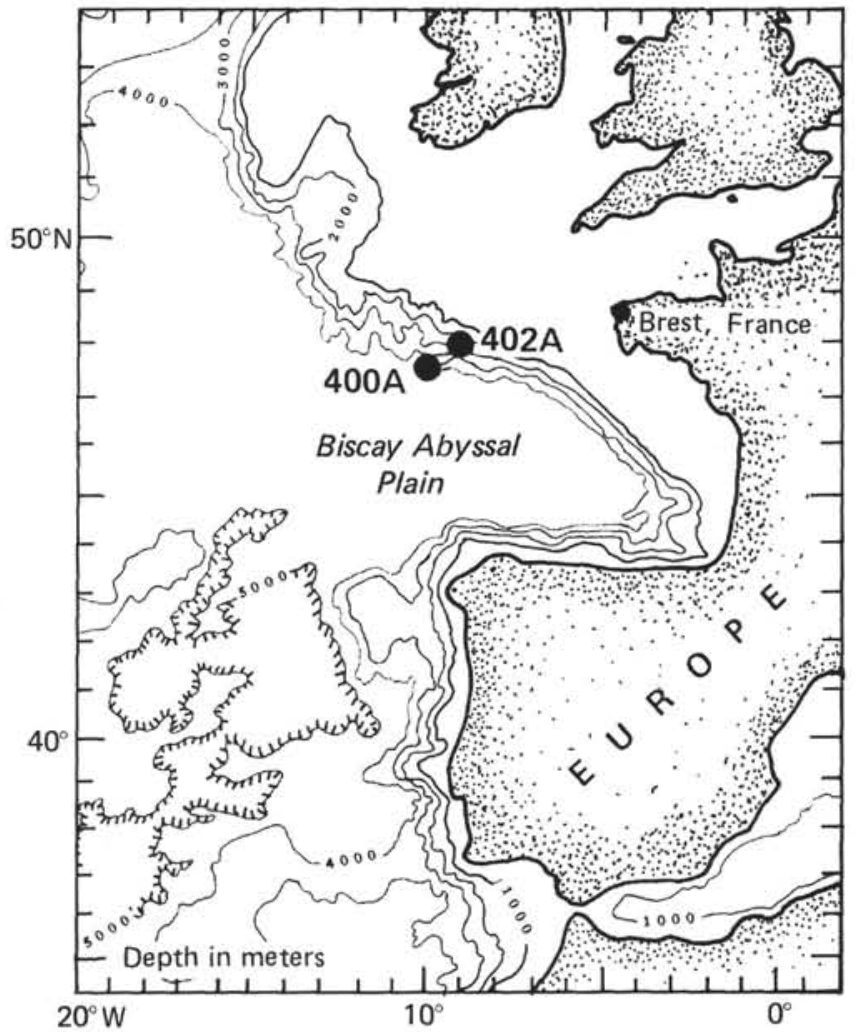

Figure 1. Location of DSDP Holes $400 \mathrm{~A}$ and $402 \mathrm{~A}$.

\section{Organic Carbon (Table 1)}

The vertical variation of organic carbon content, from base to top is as follows:

\section{Hole 400A}

A range of 0.99 to 0.19 per cent was found in the samples from Cores 72 to 68 (upper Aptian) plus the samples from Cores 66-4 and 66-1 (Albian). A higher content characterizes the Albian interval between Cores 66-4 (54-55 $\mathrm{cm})$ and $64-4$ (1.00 to 2.35 per cent). It is overlain by the richest organic sequence of the section (1.61 to 2.64 per cent) with Cores 64-2 to 3 to 63-2 located on each side of the late to middle Albian boundary. Cores 63-3 to 61, CC from the upper Albian show two populations both with low carbon contents: the poorest one ( 0.15 to 0.33 per cent) is present throughout the whole interval whereas the other ( 0.55 to 0.89 per cent) is located between Cores $63-1$ and $62-2$ to $62-4$. 


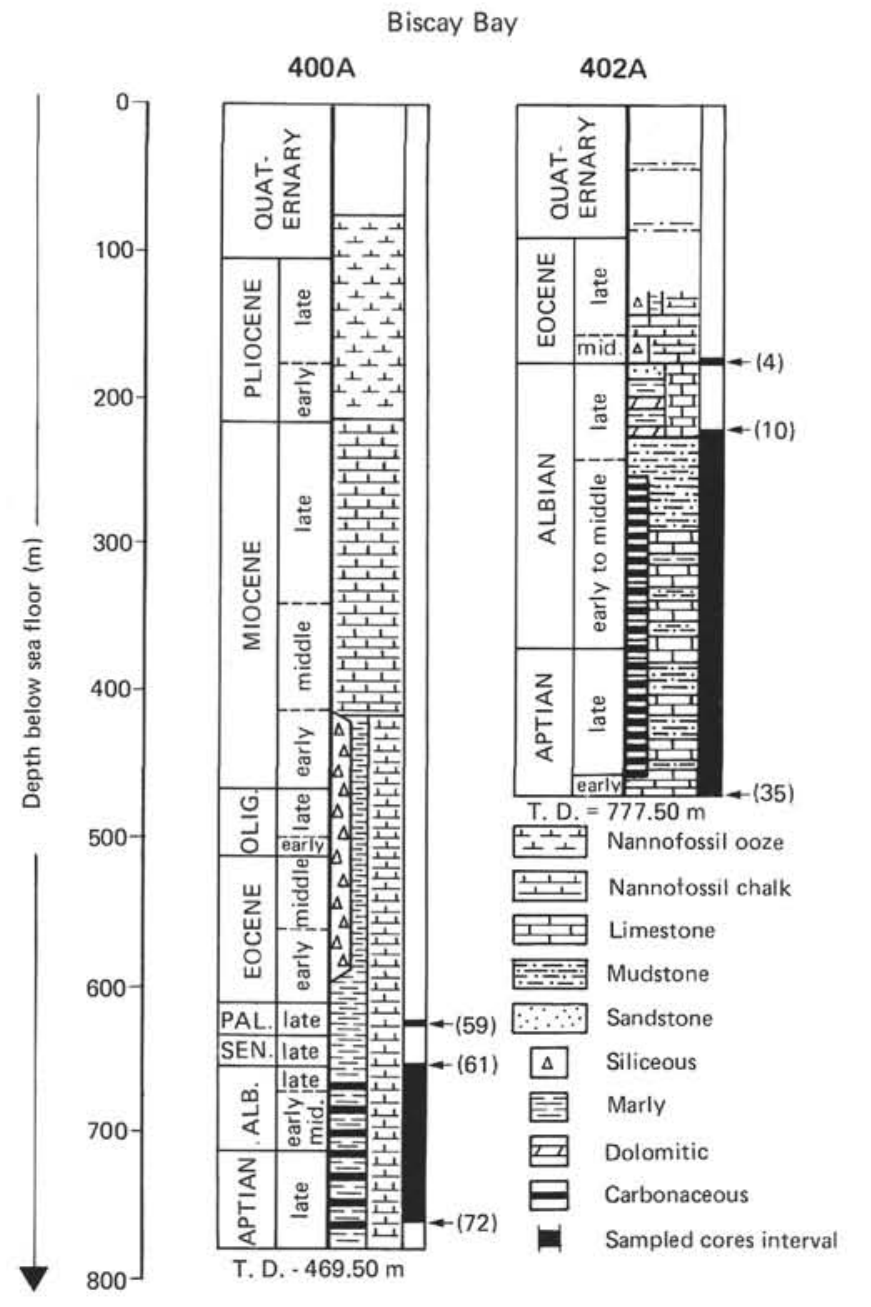

Figure 2. Stratigraphic location of sampled cores.

\section{Hole 402A}

The lowest samples from Cores 35 and 34 from the lower Aptian show the lowest content ( 0.32 to 0.56 per cent) of the series. All other samples from Cores 33 to 10 have a content close to 1.00 per cent or higher. The highest content (11.47 weight per cent) was found for a coaly sample of Core 33-2 (127-128 cm). An organic carbon-rich interval (2.06 to 2.99 per cent) can be distinguished in Cores 32 to 30 (upper Aptian) and a lean interval ( 0.20 to 1.18 per cent) for the uppermost Cores 13 to 10, mostly of upper Albian age.

\section{Pyrolysis Assay and Organic Matter Characterization (Table 1, Figures 4, 5)}

This method (Espitalié, et al., 1977) allows characterization of sedimentary organic material and its maturation steps. Pyrolysis data can also be used for plotting a geochemical log.

Pyrolysis was performed on board Glomar Challenger for the first time during Leg 48. Pyrolysis, combined with visual examination of the cores, led to the following conclusions: ". . . Aptian black shales at Site 400 were terrestrial in origin. .. ." and "Maturity data. . . from
Sites 400 and 402 indicate a very low temperature history. ..."

For this further study the characterization of organic matter, its vertical distribution and comparison between sites, were examined.

\section{Characterization of the Organic Matter}

Table 1 and Figures 4a, 4b show the values of hydrogen and oxygen indexes related to weight of organic carbon. (Espitalié et al., 1977). They allow a characterization of the organic matter as follows:

\section{Hole $400 \mathrm{~A}$}

The most organic-rich interval (Cores 64 to 63 , middle and upper Albian) corresponds to samples located above the evolution path of kerogen type III. This indicates that it belongs to unaltered material of predominantly continental origin. The other samples of the same interval and of the underlying series correspond to very low hydrogen indexes (less than 45) and the oxygen index varies from 40 to 300 . The very low hydrogen indexes and the high oxygen index values in some intervals can be related to alteration by reworking and/or oxidation before sedimentation.

\section{Hole $402 A$}

A coaly sample (Section 33-2) is located along the lower part of the evolution path of kerogen type II. All the other samples show a low hydrogen index (less than 40) and an oxygen index between 39 and 200 . This suggests again a material comparable to kerogen type III but extensively altered.

\section{Vertical Distribution of the Organic Matter}

Although the organic matter has a similar origin at the two sites, some more detailed information can be deduced from pyrolysis. In Figure 5 organic carbon content and hydrogen index related to weight of rock are plotted together with the geological sections in the same way as the Cretaceous sediments of Leg 47B (Deroo et al., 1979b); three levels of organic carbon and two others for hydrogen indexes are indicated symbolically on the plots.

\section{Hole 400 A}

The cored Albian/Aptian series of some 125 meters thickness can be characterized from base to top as follows (Figure 5a).

The first interval (Cores 72 to 66 ) presents low hydrogen indexes (less than $0.10 \mathrm{mg}$ of hydrocarbons per gram of rock) for a low organic carbon content of some 0.75 to 0.19 weight per cent.

The second interval (Cores 66 to Secton 64-4) with an organic carbon content of about one per cent reveals also low hydrogen indexes (less than $0.24 \mathrm{mg}$ of hydrocarbons per gram of rock). Characteristics of the two previously defined intervals are present in Core 66.

The third interval (Section 64-2 to 63-2) presents a larger organic carbon content (up to 2.64 per cent) and also larger hydrogen indexes (1.58 to $2.64 \mathrm{mg}$ ). The hydrogen and oxygen indexes indicate a predominantly kerogen material of type III. 


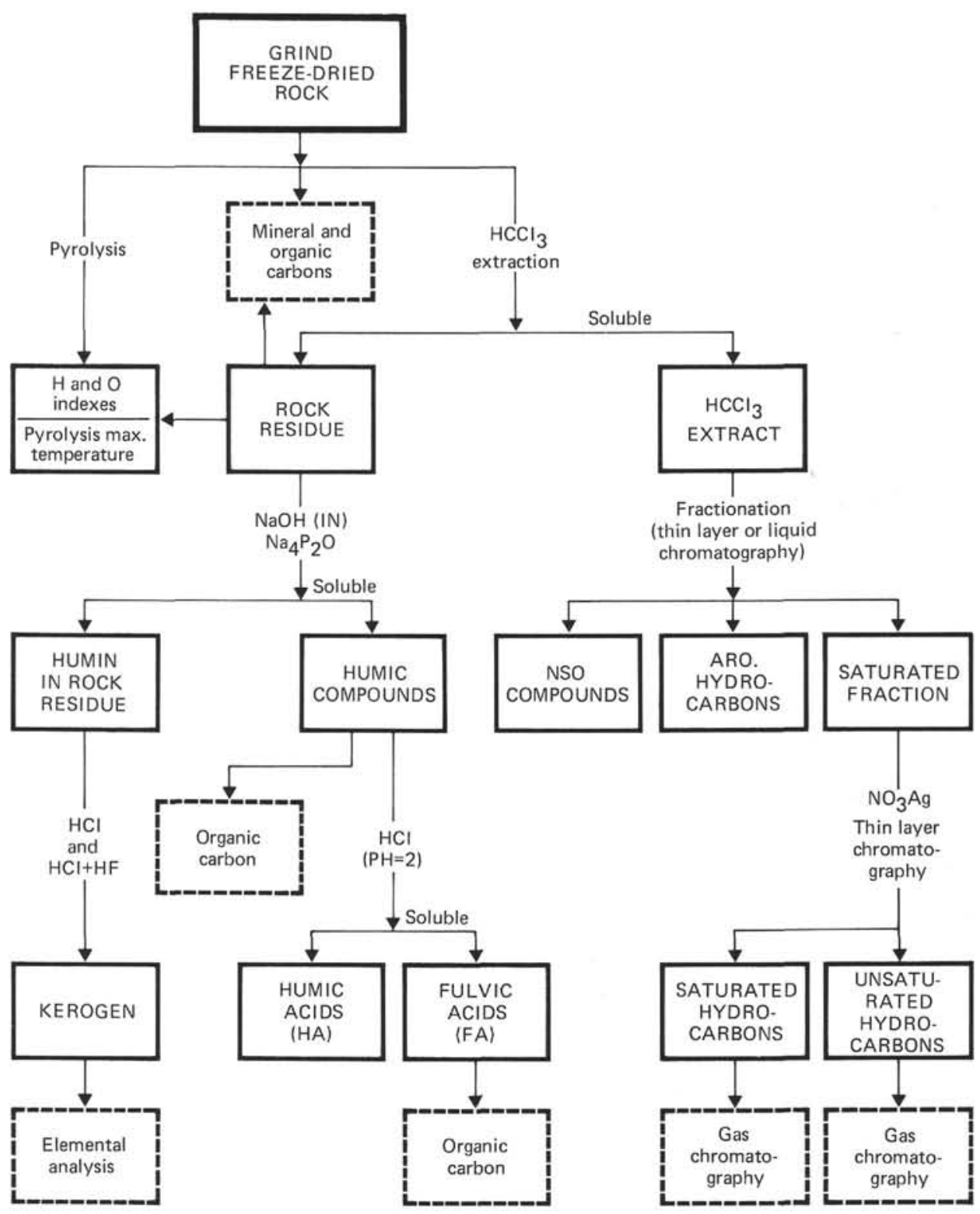

Figure 3. Schematic analytical processes.

In the fourth and last interval (Core 63, Section 3 to Core 61) low organic contents ( 0.32 per cent or less) and hydrogen indexes are found together with a material of intermediate organic carbon content ( 0.50 to 0.90 per cent) and hydrogen indexes (i.e., comparable with the second interval).

\section{Hole $402 A$}

At both ends of the sampled section two intervals can be distinguished (Figure $5 \mathrm{~b}$ ). The bottom interval (interval 1), for Cores 35 and 32, contains the lowest organic carbon content but hydrogen indexes are comparable to those found in the overlying interval (Cores 32 to 12 ). In contrast, the top interval (interval 3; Cores 13 to 11), despite organic carbon contents up to one per cent, shows very low hydrogen indexes (less than $0.10 \mathrm{mg}$ of hydrocarbons per gram of rock). The main interval (interval 2; Cores 32 to 12) is defined by organic carbon contents of more than one per cent, with values over two per cent for Cores 32 to 30 , and by low hydrogen indexes.

\section{Comparison of sites}

If the defined intervals from Sites 400 and 402 are compared on a stratigraphic basis with those of Site 398 (Deroo et al., 1979b) the first and last sites show closer similarities, although their Aptian to Albian series are, respectively, of about 100 meters and 600 meters thick. Thus:

1) the altered organic matter of continental origin which characterizes most of the investigated section of Site 402 between Cores 32 and 12 (interval 2, from base of upper Aptian to base of upper Albian), is only dominant at interval 2 of Site 400 and interval 3 of Site 398 in the lower to middle Albian series. 
TABLE 1

Location of Samples - Carbon and Pyrolysis Assay Data

\begin{tabular}{|c|c|c|c|c|c|c|c|c|c|}
\hline $\begin{array}{c}\text { Sample } \\
\text { (Interval in } \mathrm{cm} \text { ) }\end{array}$ & $\begin{array}{l}\text { Depth } \\
\text { Below } \\
\text { Sea } \\
\text { Floor } \\
(\mathrm{m})\end{array}$ & $\begin{array}{l}\text { Mineral } \\
\text { Carbon } \\
\text { (wt. \%) }\end{array}$ & $\begin{array}{l}\text { Organic } \\
\text { Carbon } \\
\text { (wt. \%) }\end{array}$ & $\begin{array}{l}\text { Hydrogen } \\
\text { Index } \\
\text { (mg. hydroc. } \\
\text { compounds } \\
\text { related to } \\
\text { g. of org. carb.) }\end{array}$ & $\begin{array}{l}\text { Oxygen } \\
\text { Index } \\
\text { (mg. } \mathrm{CO}_{2} \\
\text { related } \\
\text { to g. of } \\
\text { org. carb.) }\end{array}$ & $\begin{array}{l}\text { Hydrogen } \\
\text { Index } \\
\text { (mg. hydroc. } \\
\text { compounds } \\
\text { related to } \\
\text { g. of rock) }\end{array}$ & $\begin{array}{l}\text { Oxygen } \\
\text { Index } \\
\text { (mg. } \mathrm{CO}_{2}, \\
\text { related } \\
\text { to } \\
\text { g. of rock) }\end{array}$ & $\begin{array}{c}\text { Pyrolysis } \\
\text { temperature } \\
\left({ }^{\circ} \mathrm{C}\right)\end{array}$ & Age \\
\hline \multicolumn{10}{|l|}{ Hole 400A } \\
\hline $61, \mathrm{CC}$ & 654.00 & 5.60 & 0.15 & 14. & 300. & 0.02 & 0.45 & & \multirow[t]{2}{*}{ Senonian } \\
\hline $\begin{array}{l}62-1,69-70 \\
62-2,4 \\
62-3,81-82 \\
62-4,75-76 \\
62-4,104-105 \\
62-5,91-92 \\
63-1,50-51 \\
63-2,98-99 \\
63-3,29-30 \\
63-4,35-36\end{array}$ & $\begin{array}{l}654.69 \\
655.87 \\
657.81 \\
659.25 \\
659.54 \\
660.91 \\
664.00 \\
665.98 \\
666.79 \\
668.35\end{array}$ & $\begin{array}{l}5.84 \\
7.20 \\
4.40 \\
6.32 \\
6.04 \\
5.84 \\
4.72 \\
5.72 \\
5.52 \\
6.48\end{array}$ & $\begin{array}{l}0.22 \\
0.89 \\
0.77 \\
0.27 \\
0.57 \\
0.32 \\
0.55 \\
2.64 \\
0.19 \\
1.61\end{array}$ & $\begin{array}{l}15 . \\
45 . \\
28 . \\
12 . \\
18 . \\
17 . \\
40 . \\
100 . \\
13 . \\
99 .\end{array}$ & $\begin{array}{r}159 . \\
171 . \\
78 . \\
159 . \\
114 . \\
166 . \\
120 . \\
40 . \\
237 . \\
43 .\end{array}$ & $\begin{array}{l}0.03 \\
0.03 \\
0.60 \\
0.21 \\
0.10 \\
0.05 \\
0.22 \\
2.64 \\
0.02 \\
1.59\end{array}$ & $\begin{array}{l}0.35 \\
1.52 \\
0.60 \\
0.43 \\
0.65 \\
0.53 \\
0.66 \\
1.05 \\
0.45 \\
0.69\end{array}$ & $\begin{array}{l}425 . \\
434 . \\
420 .\end{array}$ & \\
\hline $\begin{array}{l}64-2,3 \\
64-2,34-35 \\
64-2,96-97 \\
64-4,104-105 \\
65-1,22-23 \\
65-2,96-97 \\
66-1,61-62 \\
66-2,29-30 \\
66-4,0-42 \\
66-4,20-21 \\
66-4,54-55\end{array}$ & $\begin{array}{l}674.68 \\
674.84 \\
675.46 \\
678.54 \\
682.72 \\
684.96 \\
692.61 \\
693.79 \\
696.50 \\
696.70 \\
697.04\end{array}$ & $\begin{array}{l}4.00 \\
1.43 \\
3.56 \\
3.12 \\
1.00 \\
1.72 \\
2.96 \\
0.60 \\
2.56 \\
0.61 \\
0.60\end{array}$ & $\begin{array}{l}2.05 \\
2.04 \\
2.17 \\
1.00 \\
0.91 \\
1.26 \\
0.31 \\
1.24 \\
0.99 \\
1.78 \\
2.35\end{array}$ & $\begin{array}{r}87 . \\
107 . \\
73 . \\
18 . \\
16 . \\
19 . \\
15 . \\
12 . \\
8 . \\
13 . \\
51 .\end{array}$ & $\begin{array}{r}86 . \\
50 . \\
47 . \\
62 . \\
56 . \\
53 . \\
213 . \\
48 . \\
183 . \\
41 . \\
26 .\end{array}$ & $\begin{array}{l}1.79 \\
2.19 \\
1.58 \\
0.18 \\
0.14 \\
0.24 \\
0.05 \\
0.14 \\
0.08 \\
0.22 \\
1.21\end{array}$ & $\begin{array}{l}1.76 \\
1.03 \\
1.01 \\
0.62 \\
0.51 \\
0.67 \\
0.66 \\
0.60 \\
1.81 \\
0.73 \\
0.61\end{array}$ & $\begin{array}{l}429 . \\
411 \\
422 \\
425 \\
422 \\
436 \\
\\
425 \\
425 \\
406 \\
425\end{array}$ & 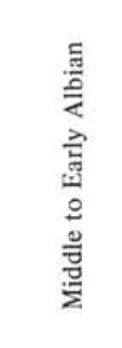 \\
\hline $\begin{array}{l}68-2,50-51 \\
68-2,66-67 \\
68-2,105-106 \\
68, \mathrm{CC} \\
69-1,103-104 \\
69, \mathrm{CC} \\
70, \mathrm{CC} \\
71-1,05-06 \\
71-1,81-82 \\
71-2,28-29 \\
72-3,74-75 \\
72-3,135-136 \\
72-4,64-65\end{array}$ & $\begin{array}{l}713.00 \\
713.16 \\
713.55 \\
714.30 \\
721.53 \\
722.00 \\
726.60 \\
738.55 \\
739.31 \\
740.28 \\
751.74 \\
752.35 \\
753.14\end{array}$ & $\begin{array}{l}0.60 \\
1.36 \\
4.44 \\
0.40 \\
3.24 \\
1.04 \\
3.00 \\
3.76 \\
3.52 \\
3.60 \\
1.28 \\
2.80 \\
0.96\end{array}$ & $\begin{array}{l}0.28 \\
0.26 \\
0.30 \\
0.25 \\
0.56 \\
0.19 \\
0.76 \\
0.27 \\
0.39 \\
0.45 \\
0.60 \\
0.48 \\
0.67\end{array}$ & $\begin{array}{r}1 . \\
7 . \\
7 . \\
11 . \\
9 . \\
0 . \\
13 . \\
16 . \\
14 . \\
7 . \\
6 . \\
7 . \\
6 .\end{array}$ & $\begin{array}{l}261 . \\
188 . \\
197 . \\
236 . \\
105 . \\
221 . \\
112 . \\
237 . \\
185 \\
187 \\
115 \\
202 \\
110\end{array}$ & $\begin{array}{l}0.00 \\
0.02 \\
0.02 \\
0.03 \\
0.05 \\
0.03 \\
0.10 \\
0.04 \\
0.05 \\
0.03 \\
0.03 \\
0.03 \\
0.04\end{array}$ & $\begin{array}{l}0.73 \\
0.49 \\
0.59 \\
0.59 \\
0.59 \\
0.42 \\
0.85 \\
0.64 \\
0.72 \\
0.84 \\
0.69 \\
0.97 \\
0.74\end{array}$ & 423. & 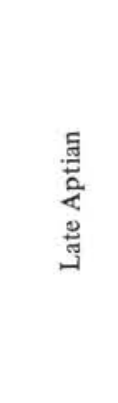 \\
\hline \multicolumn{9}{|l|}{ Hole 402A } & \multirow[b]{2}{*}{ 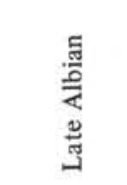 } \\
\hline $\begin{array}{l}10-1,40-41 \\
11-1,05-07 \\
11-1,4 \\
11-1,36-37\end{array}$ & $\begin{array}{l}222.90 \\
232.05 \\
232.39 \\
232.41\end{array}$ & $\begin{array}{l}3.48 \\
3.60 \\
5.24 \\
3.60\end{array}$ & $\begin{array}{l}0.20 \\
1.02 \\
0.90 \\
0.86\end{array}$ & $\begin{array}{r}55 . \\
9 . \\
12 . \\
10 .\end{array}$ & $\begin{array}{r}510 . \\
96 . \\
197 . \\
128 .\end{array}$ & $\begin{array}{l}0.11 \\
0.09 \\
0.11 \\
0.09\end{array}$ & $\begin{array}{l}1.02 \\
0.98 \\
1.77 \\
1.10\end{array}$ & 427. & \\
\hline $\begin{array}{l}12-1,39-40 \\
12-1,110-111 \\
13-1,61-62 \\
14-1,3 \\
14-1,113-114\end{array}$ & $\begin{array}{l}241.89 \\
242.60 \\
251.61 \\
261.56 \\
261.63\end{array}$ & $\begin{array}{l}4.00 \\
4.24 \\
5.88 \\
4.80 \\
4.40\end{array}$ & $\begin{array}{l}1.18 \\
0.92 \\
0.52 \\
1.12 \\
1.05\end{array}$ & $\begin{array}{r}17 . \\
5 . \\
13 . \\
15 . \\
14 .\end{array}$ & $\begin{array}{r}66 . \\
126 . \\
108 . \\
154 . \\
65 .\end{array}$ & $\begin{array}{l}0.20 \\
0.04 \\
0.07 \\
0.16 \\
0.15\end{array}$ & $\begin{array}{l}0.78 \\
1.16 \\
0.56 \\
1.73 \\
0.68\end{array}$ & 415. & \multirow{16}{*}{ 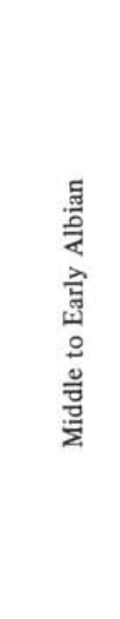 } \\
\hline $14-3,36-37$ & 263.86 & 3.60 & 1.08 & 15. & 50. & 0.16 & 0.54 & 434. & \\
\hline $15-2,129-130$ & 272.79 & 2.96 & 1.20 & 13. & 56. & 0.15 & 0.67 & 418. & \\
\hline $16-1,2$ & 279.50 & 4.28 & 1.54 & 16. & 108. & 0.25 & 1.66 & 425. & \\
\hline $16-1,59-60$ & 280.09 & 2.96 & 1.27 & 9. & 56. & 0.12 & 0.71 & 413. & \\
\hline $17-1,85-86$ & 289.85 & 3.20 & 1.50 & 21. & 57. & 0.31 & 0.85 & 425. & \\
\hline $18-1,4$ & 299.83 & 4.60 & 1.73 & 19. & 85. & 0.33 & 1.47 & 425. & \\
\hline $18-1,2$ & 299.94 & 12.00 & 0.15 & 14. & 560. & 0.02 & 0.84 & & \\
\hline $18-2,64-66$ & 300.64 & 3.60 & 1.18 & 13. & 69. & 0.15 & 0.82 & 423. & \\
\hline $18-3,07-08$ & 301.57 & 3.36 & 1.73 & 15. & 54. & 0.26 & 0.93 & 427. & \\
\hline $19-1,63-64$ & 308.63 & 3.60 & 1.46 & 21. & 50. & 0.30 & 0.73 & 449. & \\
\hline $19-2,111-112$ & 310.61 & 3.84 & 1.28 & 17. & 55. & 0.21 & 0.71 & 434. & \\
\hline $20-1,70-72$ & 318.20 & 3.20 & 1.90 & 18. & 39. & 0.35 & 0.75 & 444. & \\
\hline $20-3,53-54$ & 321.03 & 2.84 & 1.64 & 12. & 47. & 0.20 & 0.77 & 432. & \\
\hline $20-3,66-67$ & 321.16 & 3.00 & 1.57 & 20. & 47. & 0.32 & 0.74 & 437. & \\
\hline $21-3,4$ & 330.00 & 5.60 & 1.25 & 20. & 138. & 0.25 & 1.73 & 425. & \\
\hline
\end{tabular}


TABLE 1 - (Continued)

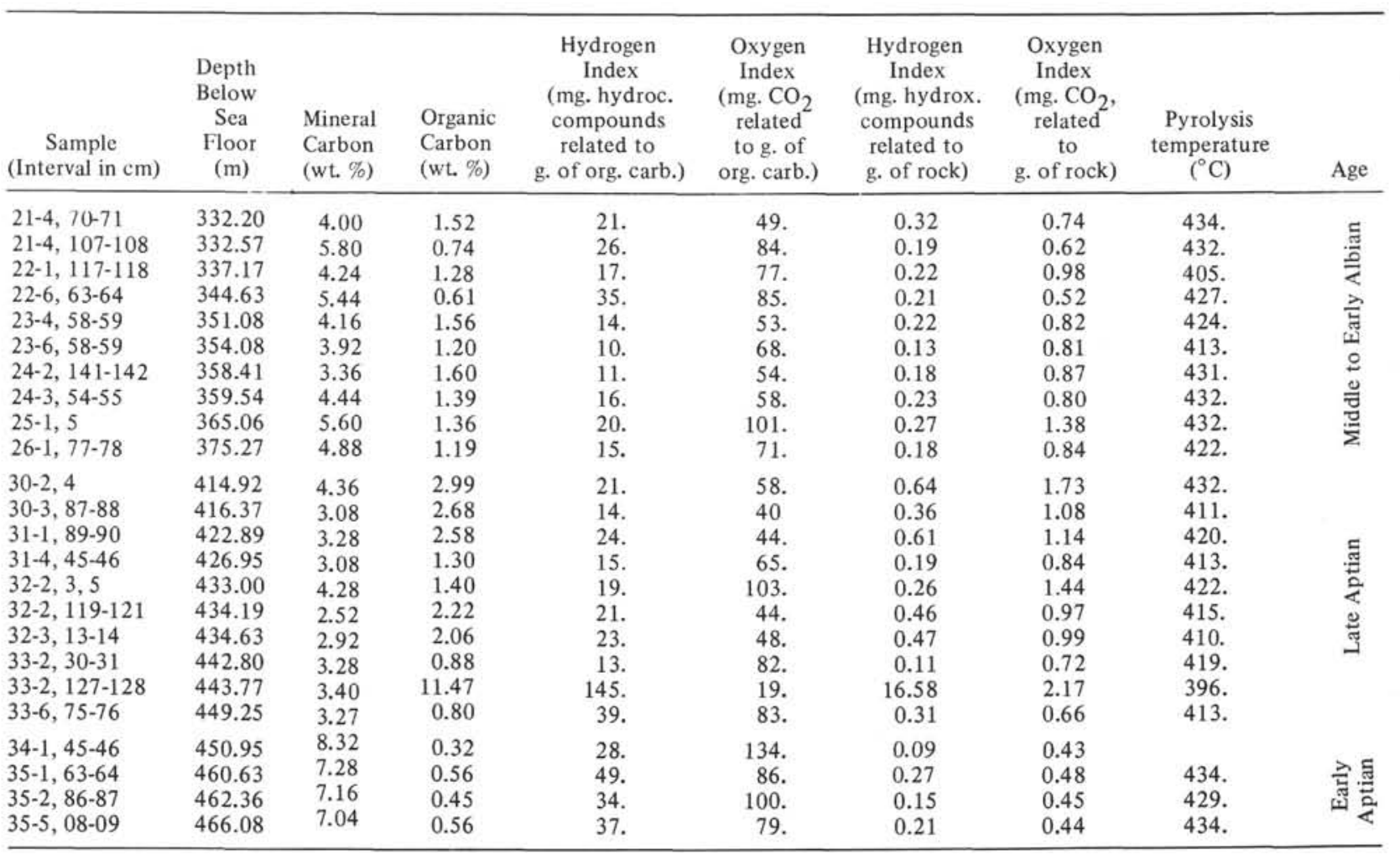

2) the richest organic sequence occurs in beds of upper Aptian age (Cores 32 to 30 ) at Site 402, whereas it is Albian at Site 400 (interval 3). The material, which is of continental origin in both cases, is altered at Site 402 , but unaltered at Site 400 .

3) organic matter of upper Aptian age reveals the same characters for Sites 400 (interval 1) and 398 (interval 2) i.e., organic contents less than 1.0 per cent together with very poor hydrogen indexes (less than $0.10 \mathrm{mg} / \mathrm{g}$ of rock).

4) comparison of upper Albian strata at Site 398 (interval 4, upper part) with that from Site 400 (interval 4) shows that they have low organic carbon contents ( 0.5 per cent, or less) related to poor hydrogen indexes $(0.20 \mathrm{mg} / \mathrm{g}$ of rock, or less).

The differences in organic matter distribution between Sites 400 and 402 , which are geographically close to each other, are striking. A similar contrast was recognized from on-board conclusions about paleobathymetry; these conclusions, inferred from ecological and seismic data for Site 402 ". . . 50 meters water depth for deposition of Albian-Aptian section. . ." against ". . . an approximate paleodepth for the Albian at Site 400 of 2200 meters. . ," Perhaps the bathymetry can account for part of the differences in organic matter distribution between Sites 400 and 402 .

Whatever may be the answer, the study helps to define the nature and the origin of the organic material. It also indicates that detrital material may distinguish different modes of preservation. If the environmental relationships are confirmed by sedimentological studies on the Albo-Aptian sediments from Sites 398 and 400, some light would be cast on paleogeography of the eastern part of the Atlantic.

\section{Organic Maturity}

The temperature of the maximum pyrolysis peak (Table 1) during the pyrolysis assays is in the $400-440^{\circ} \mathrm{C}$ range and corresponds to the immature stage (before the principal zone of oil formation). All the observed data for Sites 400 and 402 , except two, fall in the range found previously for DSDP material from the Cretaceous of the Atlantic Ocean.

\section{Humic Compounds}

Six samples from Cores 64 and 66 from Site 400 and Cores 14, 21, 25 and 30 from Site 402 (Table 2) were selected for the separation of humic compounds. In Table 2 the content of humic compounds (humic + fulvic acids) is expressed as percentage of the total organic carbon contained in these compounds. The latter values comprise, for immature type III material, more than 15 per cent of total organic carbon (Huc et al., 1978). Such material is indicated at Site 402 where the humic carbon content varies from 19 to 23 percent.

The contents of the two samples from Site 400 are abnormally low if they are considered as immature material of type III as suggested by pyrolysis and kerogen analysis. For the moment no explanation for the low humic content can be given. 

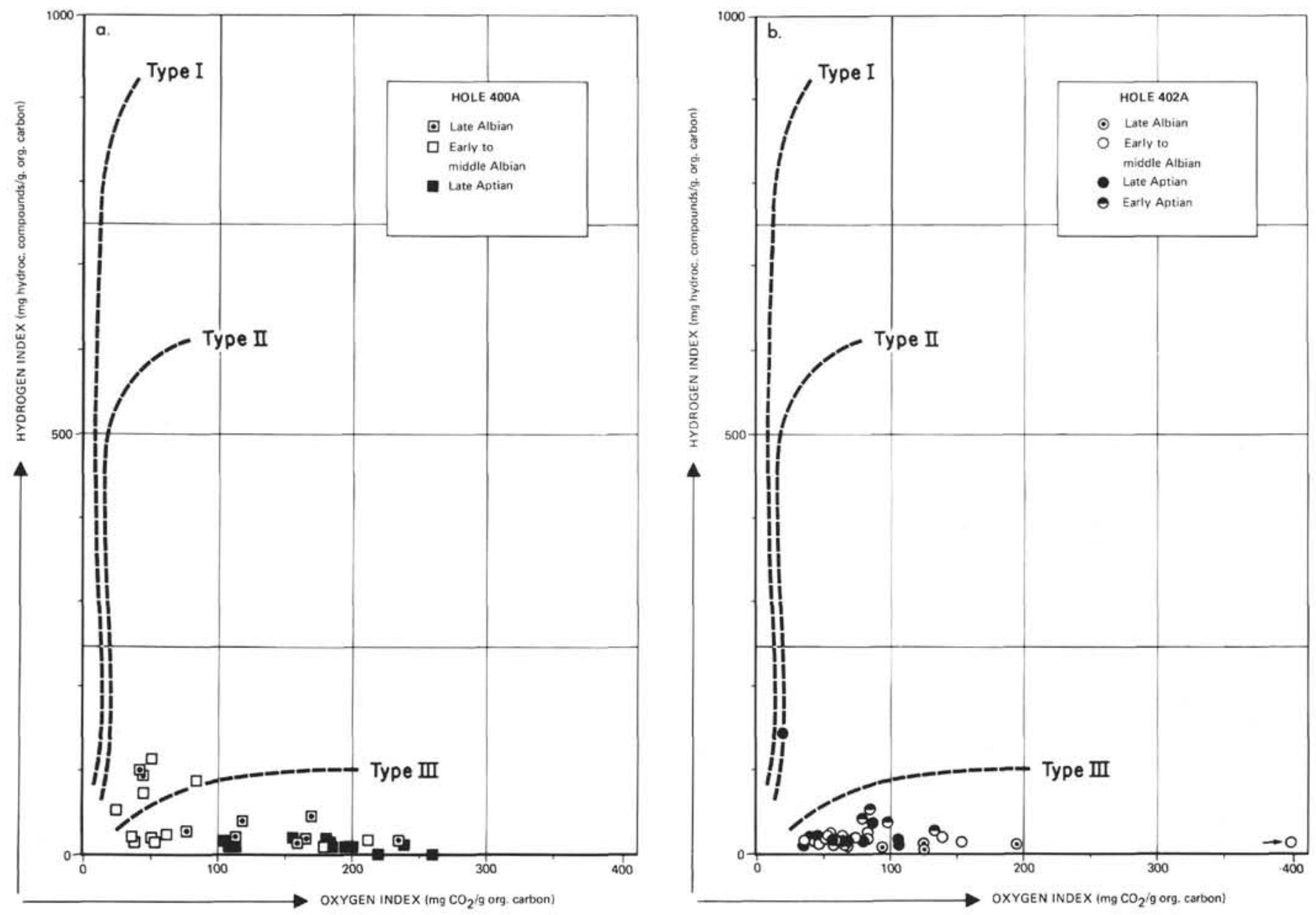

Figure 4. Pyrolysis assays. Hydrogen and oxygen indexes (data related to organic carbon). (a) Hole 400A, (b) Hole $402 \mathrm{~A}$.

\section{Kerogen Fraction (Table 3, Figure 6)}

Kerogen elemental analysis was made on the same samples selected for the study of humic compounds. The preparation used a $\mathrm{HCl}$ and $\mathrm{HF}$ acidic treatment under nitrogen atmosphere. The data (Table 3) are plotted on a Van Krevelen diagram (Figure 6) and compared to the three reference kerogen evolution paths of types I, II, and III (Tissot et al., 1974). The six kerogen values are located beneath the hydrogen-poor type III trend which is of continental origin. Most of the data are also lower than the known domain of kerogen existence. A detrital origin would account for such values. In addition, alteration/oxidation of this material prior to sedimentation would explain the abnormally low hydrogen content.

\section{Chloroform Extracts (Table 4, Figure 7)}

The six previously studied samples generally provided a low extract (30 to $10 \mathrm{mg}$ ). Similarly, the ratio of extract to organic carbon content is low (0.004 to 0.009$)$. No quantitative analysis was made, but fractionation by thin-layer chromatography was attempted (Huc et al., 1976). It provided some saturated + unsaturated fractions for gas chromatography (G.C.) analysis. Gas chromatography shows, for all the samples, a normal alkane distribution in the $C_{15}$ to $C_{30}$ interval with an odd upon even carbon number predominance in the $\mathrm{C}_{21}+$ range. This type of distribution is commonly related to higher plant material. Samples from Site 402 also reveal a $C_{15}$ and $C_{16} n$-alkanes mode as found in lipids of algal origin. Cyclic compounds are also detected in chromatograms in the $\mathrm{C}_{30}$ region, especially for all the samples from Site 402 . They are found in the saturates (Figure 7), being absent or minor components in the unsaturated fraction.

\section{CONCLUSIONS}

The Cretaceous organic matter studied at Sites 400 and 402 in the Bay of Biscay was essentially of continental and detrital origin, even for the carbonaceous beds. Intervals were defined using pyrolysis and organic carbon data. Despite their geographic proximity, an important difference during the Albian/Aptian existed between Sites 400 and 402 , whereas a closer relationship existed during late Aptian to late Albian time, between Sites 400 and 398 .

All the analyzed samples indicate an immature stage of evolution which is in agreement with other studied DSDP samples from the Cretaceous rocks of the Atlantic Ocean.

\section{ACKNOWLEDGMENTS}

The authors are indebted to Dr. C. Cornford, KFA, Jülich, for his comments, and for reviewing the present paper. 
a.

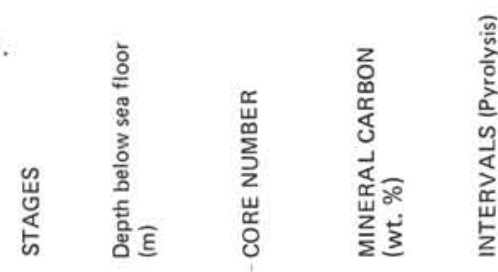

HOLE 400A

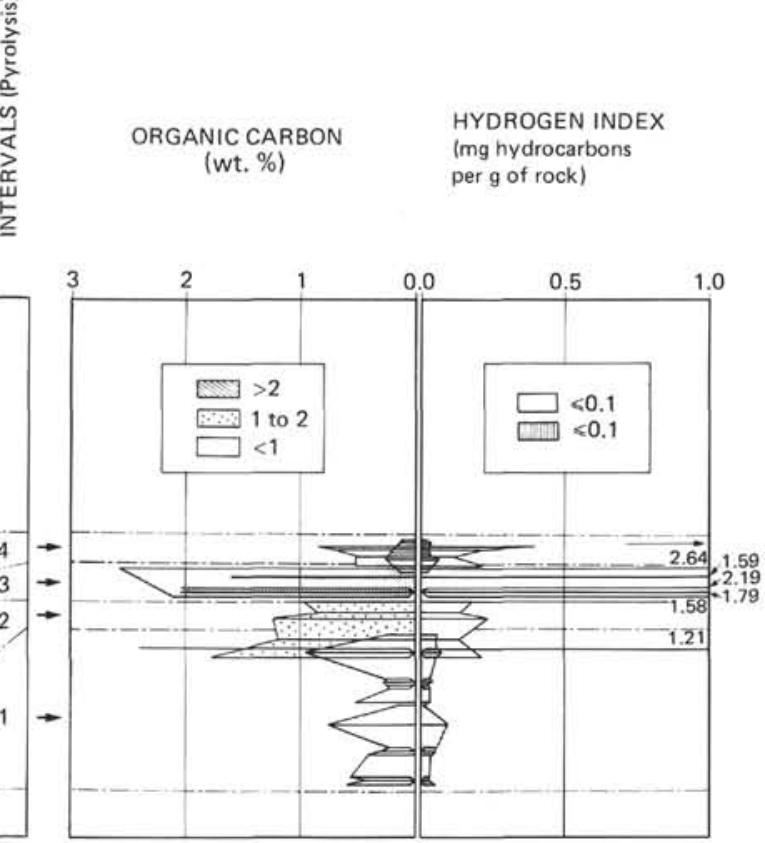

T.D. $=777.50 \mathrm{~m}$
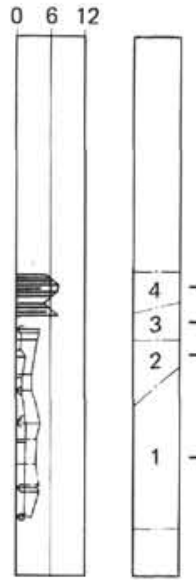

ing hydrocarbons

per $\mathrm{g}$ of rock
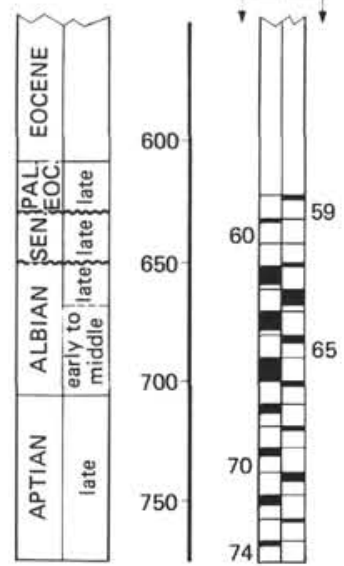

$$
\text { T.D. }=777.50 \mathrm{~m}
$$

b.

趂

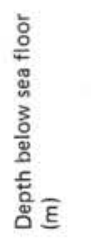

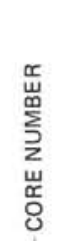

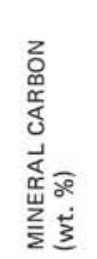

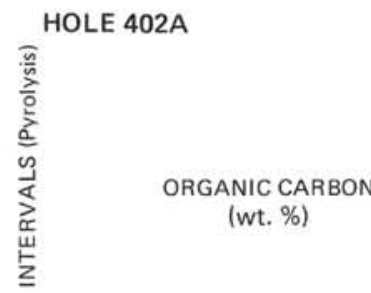

HYDROGEN INDEX

(mg hydrocarbons

per $g$ of rock)
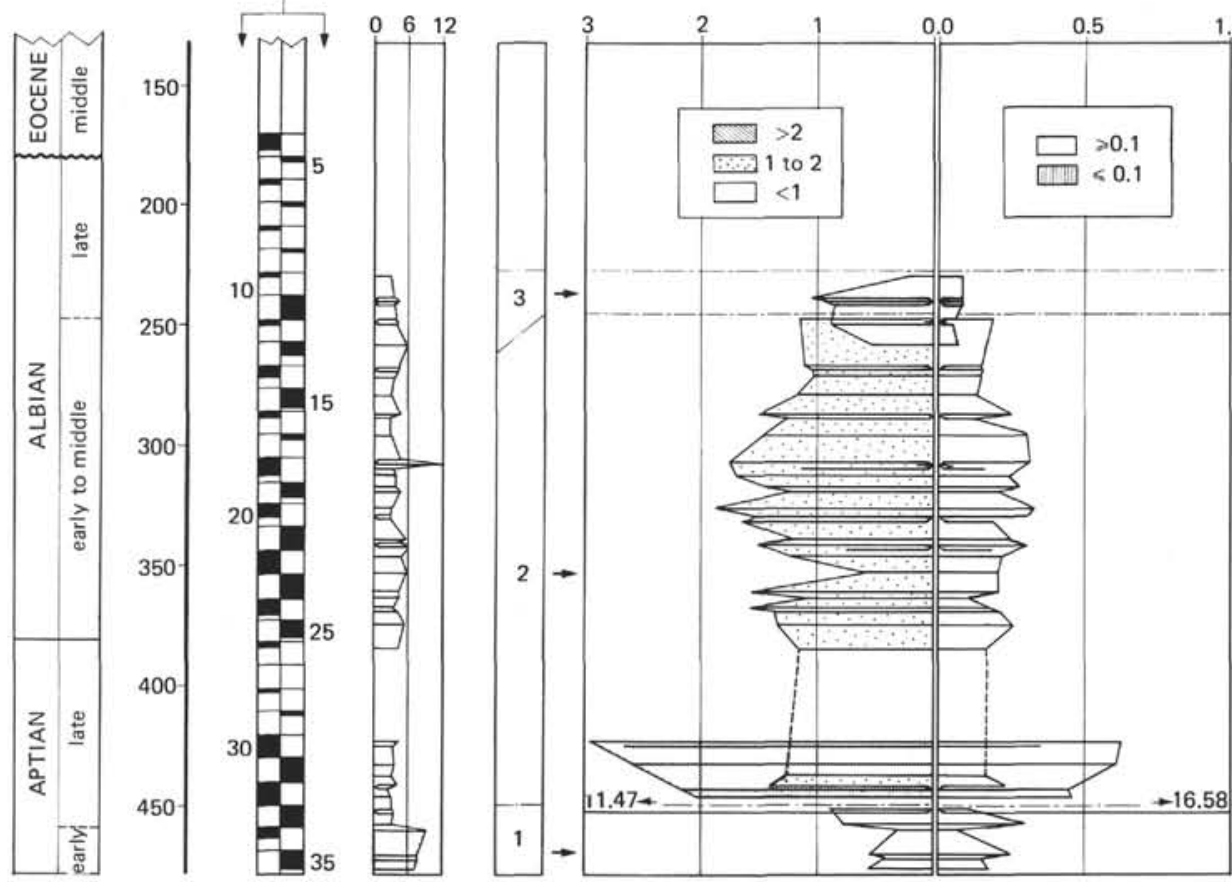

T. D. $=469.50 \mathrm{~m}$

Figure 5. Pyrolysis assays. Vertical distribution of mineral and organic carbons and hydrogen index related to the weight of rock. (a) Hole $400 \mathrm{~A}$, (b) Hole $402 \mathrm{~A}$. 


\section{REFERENCES}

Deroo, G., Herbin, J. P., Roucaché, J., Tissot, B. 1979a. Organic geochemistry of some organic rich shales from Hole 397A; Leg 47A, Eastern North Atlantic. In Ryan, W. B. F., von Rad, U., et al., Initial Reports of the Deep Sea Drilling Project, v. 47, Part 1: Washington (U.S. Government Printing Office).

, 1979b. Organic geochemistry of Cretaceous shales from Site 398; Leg 47B, Eastern North Atlantic. In Sibuet, J. C., von Rad, U., et al., Initial Reports of the Deep Sea Drilling Project, v. 47, Part 2: Washington (U.S. Government Printing Office).

Espitalié, J., Laporte, J. L., Madec, M., Marquis, F., Leplat, P., Paulet, J., and Boutefeu, A. 1977. Méthode rapide de caractérisation des roches mères, de leur potentiel pétrolier et de leur degré d'évolution, Rev. Inst. Franç. Pétrole, v. 32, p. $23-42$.
Huc, A.Y., Roucaché, J., Bernon, M., Caillet, G., and Da Silva, M., 1976. Application de la chromatographie sur couche mince à l'étude quantitative et qualitative des extraits de roche et des huiles, Rev. Inst. Franç. Petrole, v. 31, p. 67-98.

Huc, A. Y. and Durand, B., 1977. Occurrence and significance of humic acids in ancient sediments, Fuel, v. 56, p. 73-80.

Huc, A. Y., Durand, B., and Monin, J. C., 1978. Humic compounds and kerogens in cores from Black Sea sediments, Leg 42B, Holes 379A, B and 380A. In Ross, D., Neprochnov, Y., et al., Initial Reports of the Deep Sea Drilling Project, v. 42, Part 2: Washington (U.S. Government Printing Office), p. 737-749.

Tissot, B., Durand, B., Espitalié J., and Combaz, A., 1974. Influence of the nature and diagenesis of organic matter in the formation of petroleum, Am. Assoc. Petrol. Geol. Bull., v. 58, p. $499-506$.

TABLE 2

Humic Compounds - Organic Carbon Content

\begin{tabular}{|c|c|c|c|c|}
\hline \multirow[b]{2}{*}{$\begin{array}{c}\text { Sample } \\
\text { (Interval in } \mathrm{cm} \text { ) }\end{array}$} & \multirow[b]{2}{*}{$\begin{array}{l}\text { Depth } \\
\text { Below } \\
\text { Sea } \\
\text { Floor } \\
\text { (m) }\end{array}$} & \multirow[b]{2}{*}{$\begin{array}{l}\text { Total } \\
\text { Organic } \\
\text { Carbon } \\
\text { (wt. \%)a }\end{array}$} & \multicolumn{2}{|c|}{ Humic Compounds } \\
\hline & & & $\begin{array}{l}\text { Humic } \\
\text { Carbon } \\
(\%) \\
\text { related } \\
\text { to rock) }\end{array}$ & $\begin{array}{c}\text { Humic } \\
\text { Carbon } \\
\text { Versus } \\
\text { Total Org. } \\
\text { Carbon } \\
(\%)\end{array}$ \\
\hline \multicolumn{5}{|l|}{ Hole 400A } \\
\hline $\begin{array}{l}64-2 \text { to } 64-3 \\
66-4,0-42\end{array}$ & $\begin{array}{l}674.68 \\
696.50\end{array}$ & $\begin{array}{l}2.09 \\
0.93\end{array}$ & $\begin{array}{l}0.12 \\
0.08\end{array}$ & $\begin{array}{l}6 \\
9\end{array}$ \\
\hline \multicolumn{5}{|l|}{ Hole 402A } \\
\hline $\begin{array}{l}14-1 \text { to } 14-3 \\
21-321-4 \\
25-1 \text { to } 25-5 \\
30-2 \text { to } 30-4\end{array}$ & $\begin{array}{l}261.56 \\
330.00 \\
365.06 \\
414.92\end{array}$ & $\begin{array}{l}0.95 \\
1.24 \\
1.30 \\
2.97\end{array}$ & $\begin{array}{l}0.22 \\
0.27 \\
0.24 \\
0.60\end{array}$ & $\begin{array}{l}23 \\
22 \\
19 \\
20\end{array}$ \\
\hline
\end{tabular}

${ }^{\text {a After }} \mathrm{CHCl}_{3}$ extraction.

TABLE 3

Kerogens - Elemental Composition and Ash Content

\begin{tabular}{|c|c|c|c|c|c|c|c|c|c|c|}
\hline \multirow{2}{*}{$\begin{array}{c}\text { Sample } \\
\text { (Interval in } \mathrm{cm} \text { ) }\end{array}$} & \multirow{2}{*}{$\begin{array}{l}\text { Depth } \\
\text { Below } \\
\text { Sea } \\
\text { Floor } \\
(\mathrm{m})\end{array}$} & \multicolumn{6}{|c|}{ Weight Per Cent, on Ash-Free Basis } & \multirow{2}{*}{$\begin{array}{l}\text { Ashes } \\
\text { (wt. \%) }\end{array}$} & \multicolumn{2}{|c|}{ Atomic } \\
\hline & & $\mathrm{C}$ & $\mathrm{H}$ & $\mathrm{N}$ & o & $\mathrm{S}$ & $\mathrm{Fe}$ & & $\mathrm{H} / \mathrm{C}$ & $\mathrm{O} / \mathrm{C}$ \\
\hline \multicolumn{11}{|l|}{ Hole 400A } \\
\hline $\begin{array}{l}64-2 \text { to } 64-3 \\
66-4,0-42\end{array}$ & $\begin{array}{l}674.68 \\
696.50\end{array}$ & $\begin{array}{l}44.54 \\
37.59\end{array}$ & $\begin{array}{l}2.81 \\
1.74\end{array}$ & $\begin{array}{l}1.99 \\
0.77\end{array}$ & $\begin{array}{l}12.63 \\
14.33\end{array}$ & $\begin{array}{l}18.92 \\
19.98\end{array}$ & $\begin{array}{l}16.14 \\
16.37\end{array}$ & $\begin{array}{l}22.00 \\
27.80\end{array}$ & $\begin{array}{l}0.76 \\
0.55\end{array}$ & $\begin{array}{l}0.21 \\
0.28\end{array}$ \\
\hline \multicolumn{11}{|l|}{ Hole 402A } \\
\hline $\begin{array}{l}14-1 \text { to } 14-3 \\
21-3 \text { and } 21-4 \\
25-1 \text { to } 25-5 \\
30-2 \text { to } 30-4\end{array}$ & $\begin{array}{l}261.56 \\
330.00 \\
365.06 \\
414.92\end{array}$ & $\begin{array}{l}36.29 \\
43.35 \\
44.54 \\
39.83\end{array}$ & $\begin{array}{l}1.83 \\
2.16 \\
2.14 \\
2.25\end{array}$ & $\begin{array}{l}1.58 \\
1.53 \\
1.08 \\
1.09\end{array}$ & $\begin{array}{l}12.80 \\
15.60 \\
15.53 \\
16.12\end{array}$ & $\begin{array}{l}18.92 \\
16.22 \\
17.78 \\
20.22\end{array}$ & $\begin{array}{l}16.67 \\
12.35 \\
14.55 \\
16.44\end{array}$ & $\begin{array}{l}31.60 \\
22.70 \\
23.66 \\
25.20\end{array}$ & $\begin{array}{l}0.60 \\
0.60 \\
0.58 \\
0.69\end{array}$ & $\begin{array}{l}0.26 \\
0.27 \\
0.26 \\
0.30\end{array}$ \\
\hline
\end{tabular}




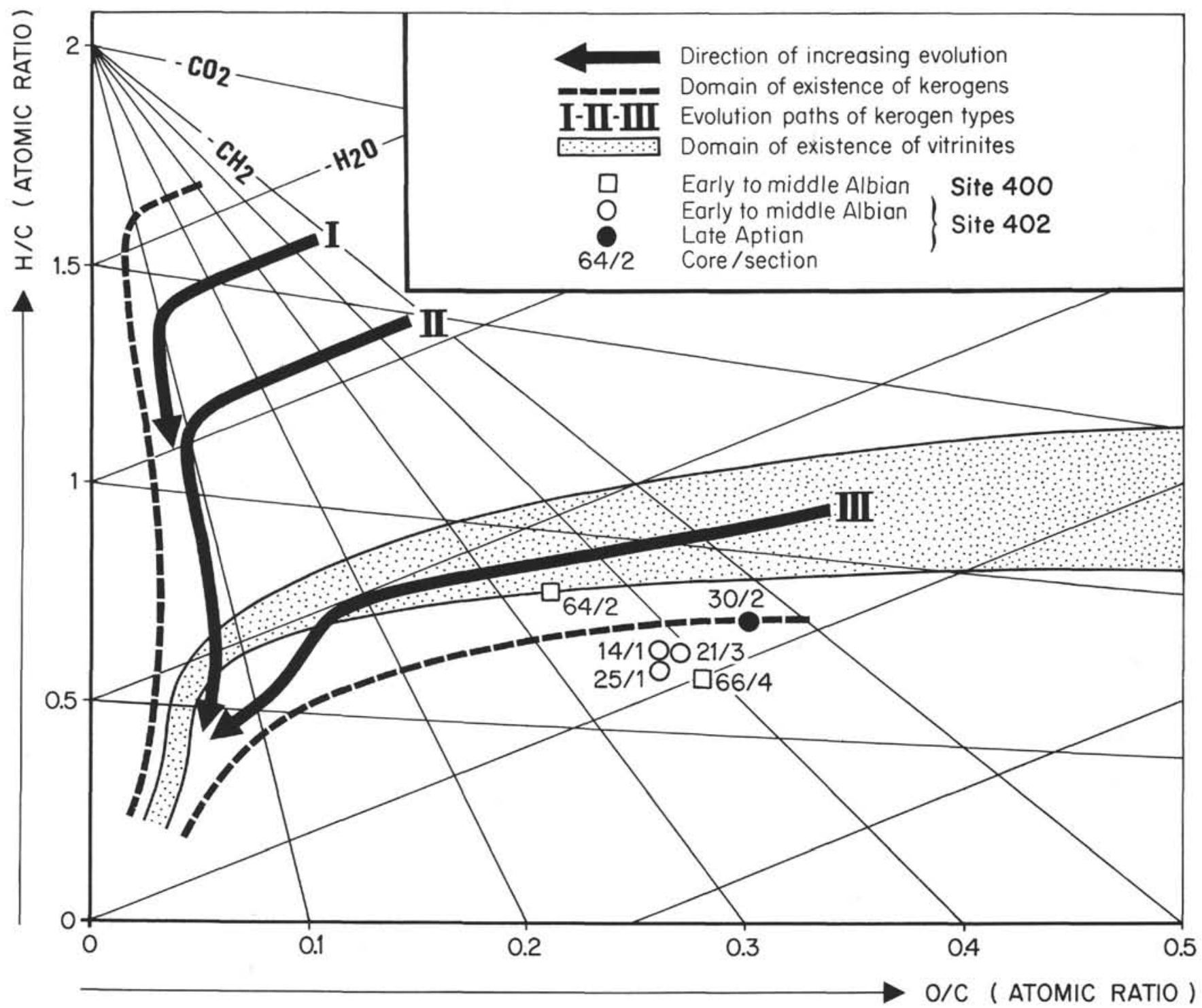

Figure 6. Kerogens. $\mathrm{H} / \mathrm{C}$ and $\mathrm{O} / \mathrm{C}$ diagram.

TABLE 4

Chloroform Extracts - Composition

\begin{tabular}{|c|c|c|c|c|c|c|c|}
\hline \multirow[b]{3}{*}{$\begin{array}{c}\text { Sample } \\
\text { (Interval in } \mathrm{cm} \text { ) }\end{array}$} & \multirow{3}{*}{$\begin{array}{l}\text { Depth } \\
\text { Below } \\
\text { Sea } \\
\text { Floor } \\
(\mathrm{m})\end{array}$} & \multirow[b]{3}{*}{$\begin{array}{l}\mathrm{HCCl}_{3} \\
\text { Extract } \\
\text { (wt. mg) }\end{array}$} & \multirow[b]{3}{*}{$\begin{array}{l}\text { Extract } \\
\text { Related } \\
\text { to Rock } \\
\text { (wt. \%) }\end{array}$} & \multirow{3}{*}{$\begin{array}{l}\text { Extract } \\
\text { Related } \\
\text { to Org. } \\
\text { Carbon } \\
\text { (wt.) }\end{array}$} & \multicolumn{3}{|c|}{$\begin{array}{c}\text { Thin-Layer Chromatography } \\
\text { Fractionation }\end{array}$} \\
\hline & & & & & \multirow[b]{2}{*}{$\begin{array}{c}\text { NSO } \\
\text { Compounds } \\
(\%)\end{array}$} & \multicolumn{2}{|c|}{$\begin{array}{l}\text { Hydrocarbon } \\
\text { Fractions }\end{array}$} \\
\hline & & & & & & $\begin{array}{l}\text { Aro. } \\
(\%)\end{array}$ & $\begin{array}{c}\text { Sat. }+ \\
\text { Unsat. } \\
(\%)\end{array}$ \\
\hline \multicolumn{8}{|l|}{ Hole $400 \mathrm{~A}$} \\
\hline $\begin{array}{l}64-2 \text { to } 64-3 \\
66-4,0-42\end{array}$ & $\begin{array}{l}674.68 \\
696.50\end{array}$ & $\begin{array}{l}27.5 \\
15.4\end{array}$ & $\begin{array}{l}0.016 \\
0.009\end{array}$ & $\begin{array}{l}0.0078 \\
0.0095\end{array}$ & & & \\
\hline $\begin{array}{l}\text { Hole } 402 \mathrm{~A} \\
14-1 \text { to } 14-3 \\
21-3 \text { and } 21-4 \\
25-1 \text { to } 25-5 \\
30-2 \text { to } 30-4\end{array}$ & $\begin{array}{l}261.56 \\
330.00 \\
365.06 \\
414.92\end{array}$ & $\begin{array}{l}10.5 \\
12.9 \\
19.1 \\
29.8\end{array}$ & $\begin{array}{l}0.007 \\
0.006 \\
0.007 \\
0.016\end{array}$ & $\begin{array}{l}0.0070 \\
0.0046 \\
0.0057 \\
0.0052\end{array}$ & \multicolumn{3}{|c|}{$\begin{array}{c}\text { No } \\
\text { quantitative } \\
\text { analysis }\end{array}$} \\
\hline
\end{tabular}



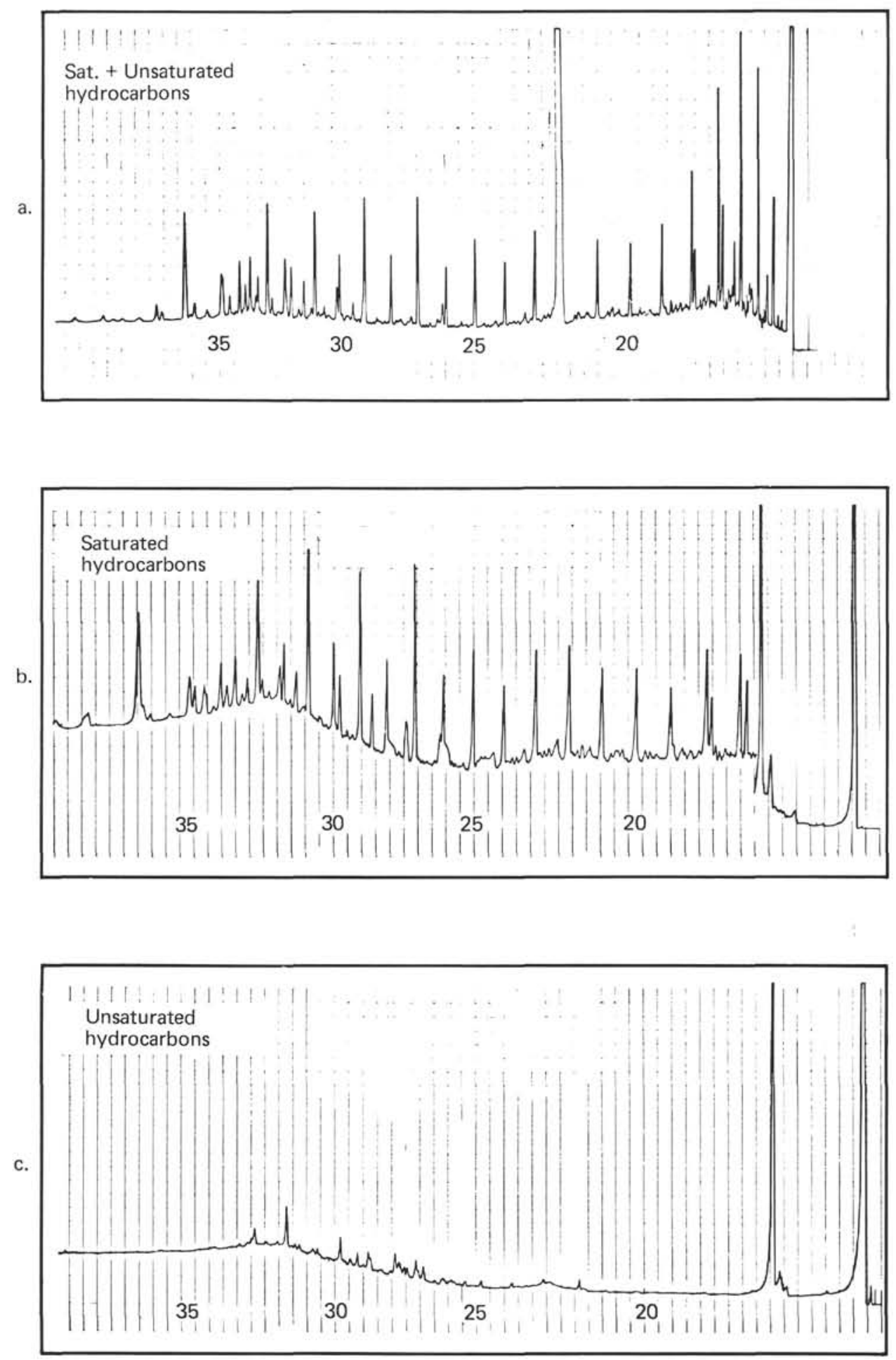

CARBON ATOM NUMBER

Figure 7. Extracts Hole 402A. Gas chromatography. (a) Core 21-3 and 4 - saturated + unsaturated fraction; (b) Composite sample, Cores 14, 21, and 25 - saturated hydrocarbons; (c) Composite sample, Cores 14, 21, and 25 - unsaturated hydrocarbons. 